\section{FIBERGLASS REINFORCED PLASTIC}

Buku Perencanaan dan Produksi Kapal Penangkap Ikan Fiberglass Reinforced Plastic merukapan hasil Penelitian kerjasama antara Politeknik Negeri Bengkalis dengan Dinas Perikanan dan Kelautan Propinsi Riau dan Dinas-Dinas Perikanan Kabupaten Kota di Propinsi Riau terkait perencanaan dan pembangunan kapal fiberglass Reinforced Plastic untuk penangkap ikan.Buku ini terdiri dari 7 bab meliputi desain kapal perikanan, sistem perlengkapan kapal, stabilitas dan seakeeping, analisa biaya pembangunan kapal, dan proses produksi kapal Fiberglass yang di kupas secara lengkap.Teknologi Kapal Fiberglass makin berkembang di Indonesia, sehingga buku ini bisa menjadi rujukan bagi semua pihak terutama galangan tradisional yang teknologinya masih tradisional dimana perencanaan kapal dan proses pembuatan kapal masih bersifat turun termurun.

Selain itu hadirnya buku ini sebagai panduan dan rujukan proses terkait perencanaan sampai dengan pembangunan kapal fiberglass Reinforced Plastic yang dapat mengantikan kapal berbahan kayu, material kayu yang sesuai standar Biro Klasifikasi Indonesia sangat sulit untuk di dapat, jika ada tentu harganya sangat mahal. Banyak galangan-galangan kapal kayu tradisonal yang ada di pesisir di Propinsi Riau yang mati suri dan sulit untuk berkembang, selain itu teknologi fiberglass metupakan teknologi yang asing dan belum familiar. Oleh sebab buku ini bisa menjadi rujukan semua pihak dalam perencanaan dan produksi kapal fiberglass Reinforced Plastic, sehingga dapat memberikan pengetahuan dalam menjalankan usaha kapal dan meningkatkan perekonomian masyarakat serta meningkatkan produksi galangan kapal dalam menyongsong perdagangan bebas Tahun 2025. KM. MEDANG KAMPAI JAYA
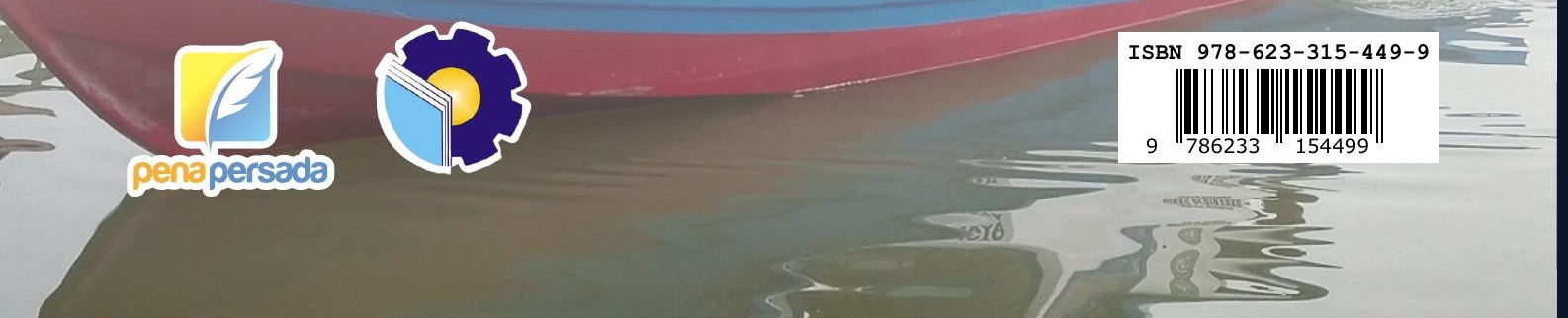

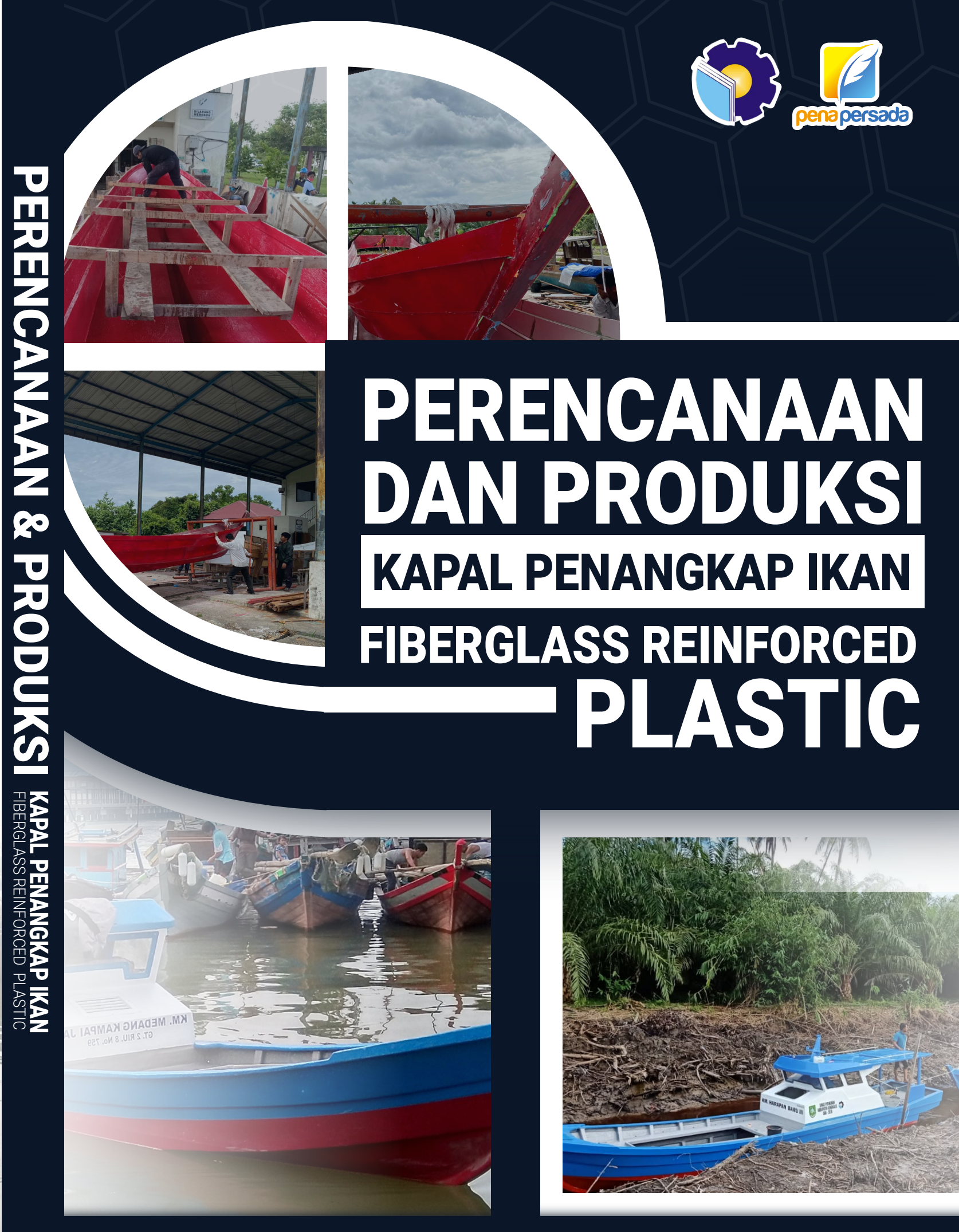

Romadhoni, S.T., M.T., | Budhi Santoso, ST., MT, | Fahendi Roher, A.Md, Fazrian, A.Md,
M. Solihin 


\title{
PERENCANAAN DAN PRODUKSI KAPAL PENANGKAP IKAN FIBERGLASS REINFORCED PLASTIC
}

\author{
Romadhoni, S.T., M.T., Budhi Santoso, ST., MT, \\ Fahendi Roher, A.Md, Fazrian, A.Md, \\ M. Solihin dan Wa Ode Siti Nur Ramadhani
}

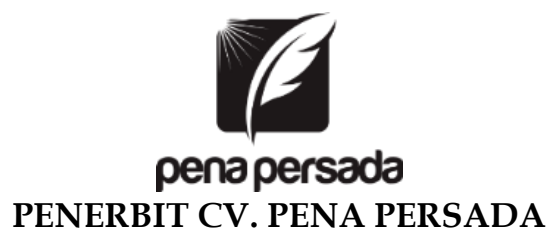




\section{PERENCANAAN DAN PRODUKSI \\ KAPAL PENANGKAP IKAN \\ FIBERGLASS REINFORCED PLASTIC}

\section{Penulis:}

Romadhoni, Budhi Santoso, Fahendi Roher, Fazrian, M.Solihin dan Wa Ode Siti Nur Ramadhani

\section{ISBN : 978-623-315-449-9}

\section{Design Cover :}

Retnani Nur Briliant

\section{Layout :}

Eka Safitry

\section{Penerbit CV. Pena Persada \\ Redaksi :}

Jl. Gerilya No. 292 Purwokerto Selatan, Kab. Banyumas

Jawa Tengah

Email : penerbit.penapersada@gmail.com

Website : penapersada.com Phone : (0281) 7771388

\section{Anggota IKAPI}

All right reserved

Cetakan pertama : 2021

Hak Cipta dilindungi oleh undang-undang. Dilarang memperbanyak karya tulis ini dalam bentuk apapun tanpa izin penerbit 


\section{PRAKATA}

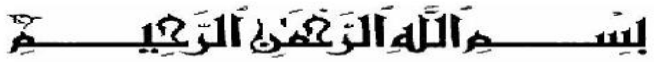

Pertama-tama penulis mengucapkan syukur alhamdulillah yang sebesar besarnya kepada Allah SWT atas segala karunia, nikmatc, rezeki dan kasih sayang yang telah diberikan-Nya, sehingga penulis dapat menyelesaikan buku ini pada waktunya dengan baik yang berjudul : "Perencanaan Dan Produksi Kapal Penangkap Ikan Fiberglass Beserta Mesin, Alat Penangkapan Ikan Dan Alat Bantu Penangkapan Ikan".

Kelangkaaan dan sulitnya mendapatkan bahan kayu tentunya membuat industri galangan kapal tradisional di pesisir mau tidak mau wajib beralih kepada teknologi fiberglass, sehingga dalam perancangan dam produksi kapal fiberglass harus mempertimbangkan aspek teknis dan nonteknis serta operasional kapal terhadap kondisi perairan dengan kriteria yang sangat berpengaruh dan dirasakan selama ini oleh pemilik, awak (ABK) serta galangan kapal.

Buku ini membahas tentang perencanaan dan fabrikasi dari kapal fiberglass meliputi bentuk badan kapal fiberglass bentuk konstruksi, sistem permesinan, perlengkapan dan peralatan geladak yang sesuai sesuai dengan kebiasaan nelayan pesisir, sehingga masyarakat tidak mengalami kesulitan dalam pengoperasian, perawatan dan perbaikan kapal fiberglass yang selama ini tekologinya dianggap asing dan sulit.

Penulis menyadari penyusunan buku ini masih jauh dari sempurna. Oleh karena itu, segala saran serta masukan yang membangun sangat penulis harapkan demi perbaikan dan dan kemajuan dalam penelisan buku.

Ucapan terima kasih kepada pihak-pihak yang membantu terlibat didalam buku ini. Semoga amalnya di terima Allah SWT sebagai amal jariyah dan buku ini dapat bermanfaat bagi kita semua khususnya yang membaca. Amin

Bengkalis, Juni 2021

Romadhoni 


\section{DAFTAR ISI}

PRAKATA

DAFTAR ISI iv

BAB 1 PENDAHULUAN 1

A. Latar Belakang 1

B. Kapal Ikan Perikanan 3

C. Jenis dan Tipe Kapal Perikanan 5

D. Hambatan Kapal Perikanan 12

E. Stabilitas Kapal Perikanan 16

F. Gerak Kapal (Seakeeping) 21

BAB 2 DESAIN KAPAL FIBERGLASS 3 GROSS TONAGE 24

A. Penentuan Ukuran Utama Kapal 24

B. Rencana garis Lines Plan $\quad 31$

C. Gambar Rencana Umum 32

D. Konstruksi Kapal 34

E. Lambung Kapal 35

F. Bangunan Atas 38

G. Penentuan Kecepatan (Speed Prediction) 41

H. Mesin Utama Kapal beserta instalasi (inboarboard Main Engine) 44

I. Dudukan Mesin / (Engine Seating) 45

J. Spesifikasi Dan Sistem Transmisi Pada Kapal Nelayan 45

BAB 3 SISTEM PERLENGKAPAN KAPAL PERIKANAN 48

A. Perlengkapan Keselamatan dan Navigasi kapal 48

B. Perlengkapan Labuh dan Tambat 48

C. Kemudi 50

D. Perlatan, Listrik dan Pompa 50

E. Alat Bantu Penangkap Ikan/Coolbox 51

F. Insulasi/Kekedapan 51

G. Railing $\quad 51$

H. Outfitting $\quad 52$

I. Finishing 52 
A. Stabilitas 54

B. Olah Gerak (Seakeping) Kapal Perikanan 62

C. Pengaruh Gerakan Kapal Terhadap Masing-masing $\begin{array}{ll}\text { Kecepatan } & 67\end{array}$

BAB 5 PEMILIHAN ALAT BANTU PENANGKAPAN IKAN $\quad 76$

A. Jaring Gilnet 76

BAB 6 ANALISA BIAYA PEMBANGUNAN KAPAL 80

A. Rencana Anggaran Biaya Kapal 1 GT dan 2 GT 80

B. Rencana Anggaran Biaya Kapal 3 GT 82

C. Rencana Anggaran Biaya Kapal 5 GT 83

BAB 7 PROSES PRODUKSI KAPAL FIBERGLASS 84

A. Bahan dan Alat 84

B. Pembuatana Cetakan Lambung 92

C. Laminasi Lambung Kapal Fiberglass 96

D. Pemasangan Konstruksi Gading 99

E. Pemasangan Mesin Utama 100

F. Bangunan Atas 101

G. Sea Trial 103

$\begin{array}{ll}\text { DAFTAR PUSTAKA } & 106\end{array}$ 


\section{PERENCANAAN DAN PRODUKSI KAPAL PENANGKAP IKAN FIBERGLASS REINFORCED PLASTIC}




\section{BAB 1 \\ PENDAHULUAN}

\section{A. Latar Belakang}

Pembangunan sektor perikanan dan Kelautan Provinsi Riau merupakan bagian integral dari pembangunan daerah sejalan dengan Visi Provinsi Riau Tahun 2020 yakni “ Menjadikan Provinsi Riau sebagai Pusat Perekonomian dan Kebudayaan Melayu dalam Lingkungan Masyarakat yang Agamis, Sejahtera Lahir dan Bathin di Asia Tenggara Tahun 2020". Untuk mewujudkan visi tersebut maka perlu dipersiapkan kerangka dasar perekonomian di semua bidang dan sektor. Demikian juga pembangunan sektor perikanan dan kelautan tidak terlepas dari Arah Kebijakan Umum Pembangunan Provinsi Riau dalam rangka Pemberantasan Kemiskinan, Kebodohan dan Peningkatan Infrastuktural.

Salah satu permasalahan yang masih menjadi kendala dalam upaya peningkatan dan pengembangan sektor perikanan terutama bidang penangkapan yakni sarana dan prasarana penangkapan ikan yang dimiliki nelayan dalam melakukan usaha penangkapan ikan, maka jelaslah bahwa kemampuan nelayan yang sangat terbatas menyebabkan usaha penangkapan yang dilakukan juga sangat terbatas sehingga tingkat pendapatan nelayan juga kurang memadai. Untuk itu Dinas Kelautan dan Perikanan Provinsi Riau hadir dengan memberikan bantuan Sarana dan Prasarana Penangkapan Ikan Kapal melalui program pengembangan perikanan tangkap.

Proponsi Riau saat ini memiliki kawasan pesisir dengan kekayaan sumber daya kelautan dan perikanan yang melimpah dan dapat menjadi andalan untuk mendukung pembangunan nasional. Pembangunan kelautan dan perikanan tersebut dilaksanakan untuk mewujudkan 3 (tiga) misi utama, yakni: 
(1) kedaulatan (sovereignity), (2) keberlanjutan (sustainability), dan (3) kesejahteraan (prosperity). Sesuai dengan petunjuk teknis tahun 2020 sektor pembangunan kelautan dan perikanan yakni perikanan tangkap menjadi sektor paling strategis sebagai penyedia bahan pangan bergizi, lapangan perkerjaan bagi masyarakat serta memberikan kontribusi dalam menghasilkan penerimaan negara, untuk mewujudkan misi kementerian kelautan dan perikanan tahun 2020-2024 sebagaimana tertuang dalam peraturan menteri kelautan dan perikanan nomor 45/permen-kp/2015 salah satu kegiatan yang menjadi prioritas pada tahun 2020 adalah bantuan sarana penangkapan ikan.

Berdasarkan penelitian Dinas Perikanan dan Kelautan Propinsi Riau (2020), tentang analisis potensi perairan. Untuk potensi perikanan air tawar sebesar 91.630,41 hektar dengan pemanfaatan 2.371.26 hektar. Kemudian, potensi perikanan air payau sebesar 45.812.07 hektar dengan pemanfaatn 749,28 hektar, Selain itu lanjutnya, untuk potensi perikanan laut sebesar 126.430,00 hektar. Dengan pemanfaatan 0,48 hektar. Sementara untuk potensi perikanan tangkap sambung Herman, sebesar 236.325,61 hektar (perairan umum daratan/PUD). Dengan pemanfaatan 126.932,46 hektar. Jumlah nelayan di Provinsi Riau mencapai 109.735 orang. Rinciannya, 59.375 orang nelayan laut, dan 50.360 orang nelayan laut perairan umum. Dari data-data tersebut bahwa potensi hasil perikanan dan kelautan Kabupaten Bengkalis belum di garap secara maksimal. Salah satu permasalahan yang masih menjadi kendala dalam upaya peningkatan dan pengembangan sektor perikanan terutama bidang penangkapan yakni sarana dan prasarana penangkapan ikan yang dimiliki nelayan Kabupaten Bengkalis dalam melakukan usaha penangkapan ikan, salah satunya armada kapal penangapan dari nelayan-nelayan di perairan Bengkalis masih tradisioanal berbahan kayu sehingga kapal tersebut tidak bisa untuk mencari ikan didaerah laut yang lebih dari 12 Mil Laut. Kiranto (2012) 
Melalui Direktorat Jenderal Perikanan Tangkap melalui Dana Alokasi Khusus tahun 2020 memberikan bantuan kepada Pemerintah Provinsi Riau memalui Dinas Perikanan mendapat bantuan Perahu/Kapal Penangkap Ikan Berukuran 1-5 GT Beserta Mesin, Alat Penangkapan Ikan Dan Alat Bantu Penangkapan Ikan, untuk meningkatkan produktivitas penangkapan dan mutu hasil tangkapan, sehingga pendapatan nelayan dapat meningkat.

Maka untuk mendukung pelaksanaan program tersebut, dalam menyosong program pemerintah dalam hal restrukturisasi kapal ikan di Indonesia, khususnya untuk daerah Provinsi Riau maka dibutuhkan penelitian lebih lanjut dalam proses perancangan kapal pengangkap ikan fiberglass berukuran 1 GT sampai dengan 5 GT dan alat penangkapan yang sesuai dengan karakteristik ombak, ikan, dan angin di wilayah penangkapan ikan Provinsi Riau.

\section{B. Kapal Ikan Perikanan}

- Kapal ikan merupakan kapal yang dioprasikan sebagai penangkap ikan.

- Kapal ikan merupakan kapal yang dirancang baik menggunakan bahan kayu, fiberglass, Almunium, dan baja yang memiliki kontruksi kapal yang berbeda-beda.

- Kapal ikan merupakan sebuah kapal yang dilengkapi juga alat tangkap ikan seperti jaring, pancing, bubu, tombak dan lain sebagainya.

Kapal dengan bobot 1-5 Gross Tonnage dengan ukuran panjang berkisar antara7 sampai 16 meter, lebar 2 sampai 2,5 meter adalah armada kapal kayu yang biasa digunakan oleh masyarakat pesisir sebagai moda transportasi maupun alat bantu penangkapan ikan oleh nelayan di perairan. Kapal dengan kapasitas muatan berkisar antara satu hingga lima ton ini dibuat oleh masyarakat sekitar perairan terbuat dari bahan utama Kayu pilihan dan khusus sebagai alat bantu dalam pememenuhan kebutuhan perekonomian sehari-hari. 
Provinsi Riau dilalui oleh beberapa Sungai dan daerah aliran sungai seperti sungai Kampar, Siak, Kuansing, Rokan dan Indragiri. Pada perairan sungai banyak dijumpai kapal kayu dengan ukuran dari satu hingga puluhan Gross Tonage (GT) dengan daerah operasi pelayaran melalui perairan sungai, juga beroperasi hingga mencapai radius empat mil di perairan selat Malaka. Armada Kapal kayu masyarakat pesisir didominasi dengan ukuran satu hinga lima hingga empat gross tonnage di Provinsi Riau yang banyak dijumpai khususnya di Kabupaten Kepulauan Meranti, Bengkalis, Rokan Hilir, Pelalawan, Indragiri Hilir dan kota Dumai. Kapal kayu dengan bobot 1-5 GT umumnya dikenal dengan sebutan kapal pompong dan kapal motor di beberapa daerah di Provinsi Riau, Kapal ini biasanya menggunakan mesin penggerak utama dengan merk Dong Feng, Yanmar, Mitsubishi serta Merk mesin cina lainnya. Kapal kayu 3 GT ini mempunyai harga jual dan pembuatan berkisar antara 15 hingga 40 juta rupiah per unit dengan daya mesin 16 hingga 40 PK.

Kapal-kapal perikanan yang ada di provinsi Riau diperoleh dengan cara memesan ataupun melalui bantuan langsung dari pemerintah. Meskipun kapal tersebut diperoleh dari bantuan pemerintah, namun metode pembangunan kapal tersebut masih dengan cara tradisional dengan melakukan perbandingan langsung terhadap jenis dan tipe kapal yang telah ada. Nurhasanah (2015). Sampai dengan tahun 2019, tercatat sebanyak 8.160 unit kapal ikan 1-5 GT yang beroperasi di Riau Pesisir (Dinas Kelautan dan Perikanan Provinsi Riau, 2020). Kapal - kapal tersebut hampir sebagian besar terbuat dengan bahan dasar kayu, dan beberapa diantaranya dengan bahan dasar fiberglass reinforced plastic (FRP). Sejak tahun 2010, pemerintah setempat mulai mengalihkan pembuatan kapal dengan bahan dasar kayu menjadi FRP karena melihat kondisi sulitnya untuk mendapatkan bahan baku kayu. Namun sangat disayangkan bahwa, kapal - kapal ikan yang dibangun dengan bahan FRP memiliki bentuk yang sangat berbeda dengan kapal kapal kayu yang telah digunakan nelayan sejak puluhan tahun yang lalu. 


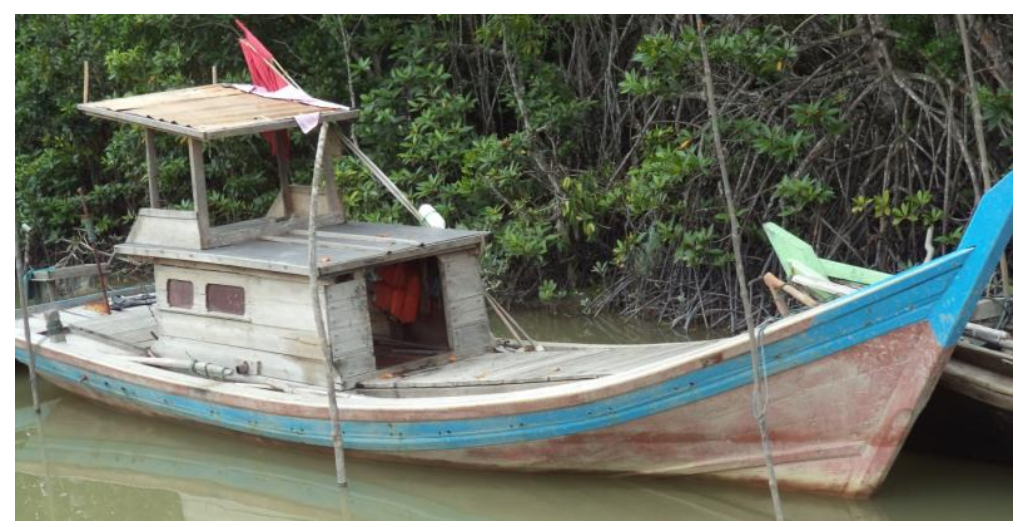

Gambar 1. 1a: Beberapa bentuk kapal kayu

(Sumber: Olahan Sendiri, 2021)

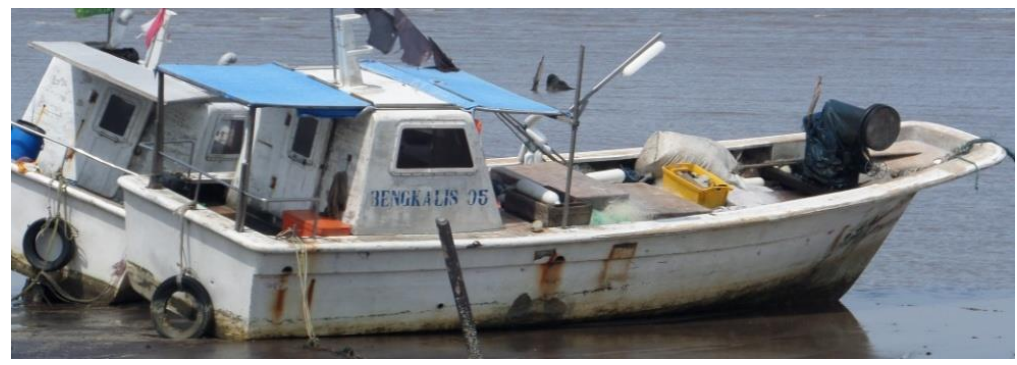

Gambar 1.1b: Beberapa bentuk kapal FRP di Kabupaten Bengkalis

(Sumber: Olahan Sendiri, 2021)

\section{Jenis dan Tipe Kapal Perikanan}

\section{Kapal Kayu}

Jenis - jenis kayu yang bisa digunakan untuk pembuatan kapal di antaranya kayu malas (Parastemonurophylum), kayu kompas (Compassia sp), kayu loban (Vitex pubercens Vahl) dan kayu meranti (Shorea sp). Masing - masing kayu tersebut digunakan pada posisi yang berbeda- beda pada proses pembuatan kapal yang dibedakan berdasarkan kelas awet dan kuat (BKI, 1989). 
Tabel 1 : Kelas jenis kayu (BKI, 1989)

\begin{tabular}{|c|c|l|c|c|l|}
\hline \multirow{2}{*}{ No } & \multirow{2}{*}{$\begin{array}{c}\text { Nama } \\
\text { Kayu }\end{array}$} & \multirow{2}{*}{ Nama Latin } & \multicolumn{2}{|c|}{ Kelas } & \multicolumn{2}{|c|}{ Pemakaian } \\
\cline { 3 - 6 } 2 & Kompas & $\begin{array}{l}\text { Compassia } \\
\text { malcensis }\end{array}$ & III - IV & I - II & Lunas \\
\hline 2 & Malas & $\begin{array}{l}\text { Parastenon } \\
\text { sp }\end{array}$ & II - III & I & $\begin{array}{l}\text { Lunas luas, Dasar mesin, } \\
\text { Linggi haluan, Linggi } \\
\text { dalam }\end{array}$ \\
\hline 3 & Loban & $\begin{array}{l}\text { Vitex } \\
\text { pubercens } \\
\text { vahl }\end{array}$ & I & I - II & $\begin{array}{l}\text { Tiang as, Tiang utama, } \\
\text { Dasar mesin, Balok geladak, } \\
\text { Gading - gading }\end{array}$ \\
\hline 4 & Meranti & $\begin{array}{l}\text { Shorea } \\
\text { platiclados }\end{array}$ & II - III & $\begin{array}{l}\text { II - } \\
\text { IV }\end{array}$ & $\begin{array}{l}\text { Leladak, Pisang-pisang, Dek } \\
\text { kapal, Dinding angin, } \\
\text { Transom, Papan tenda }\end{array}$ \\
\hline
\end{tabular}

Dalam jangka waktu tertentu kapal kayu akan mengalami pelapukan terutama untuk bagian kayu yang berhubungan atau yang tercelup langsung dengan air laut. Pelapukan kayu terjadi selain oleh proses alamiah kayu sendiri, juga disebabkan oleh hewan laut perusak seperti kapang dan teritip melekat pada tubuh kapal serta mikroba berupa jamur dan lumut (Ahmad, 2009). Selanjutnya akan dijelaskan pada tabel berikut ini mengenai jangka waktu pelapukan kapal kayu.

Tabel 2 : Jangka waktu pelapukan kapal kayu (Ahmad, 2009)

\begin{tabular}{|c|c|c|c|c|c|c|c|c|}
\hline \multirow{2}{*}{$\begin{array}{l}\text { Jenis } \\
\text { Kayu }\end{array}$} & \multicolumn{3}{|c|}{ Kuat tekan bahan $(\mathrm{kN})$} & \multirow{2}{*}{$\begin{array}{c}\text { Penampang } \\
\text { (A) }\end{array}$} & \multicolumn{3}{|c|}{ Kekuatan bahan $\left(\mathrm{kN} / \mathbf{m}^{2}\right)$} & \multirow{2}{*}{ Pemakaian } \\
\hline & 1 Thn & 10 Thn & 15 Thn & & 1 Thn & 10 Thn & 15 Thn & \\
\hline Kempas & 63.28 & 35.88 & 23.29 & 0.0009 & 703.11 & 398.67 & 258.78 & Lunas \\
\hline Loban & 53.52 & 42.37 & 41.27 & 0.0009 & 594.57 & 470.78 & 458.56 & Linggi depan \\
\hline Loban & 51.8 & 43.31 & 40.97 & 0.0009 & 575.56 & 481.22 & 455.22 & Linggi buritan \\
\hline Loban & 52.86 & 42.57 & 41.56 & 0.0009 & 587.33 & 473 & 461.78 & Gading - gading \\
\hline Meranti & 31.96 & 31.11 & 30.29 & 0.0009 & 355.11 & 345.67 & 336.56 & Dinding \\
\hline
\end{tabular}




\section{Kapal FRP}

Kapal dengan bahan dasar fiberglass saat ini menjadi alternatif pengganti kapal kayu yang paling tepat. Meskipun bahan fiberglass memiliki campuran bahan kimia yang sulit terurai sehingga dikhawatirkan akan menyebabkan terjadinya kerusakan lingkungan, akan tetapi sebagai pengganti kapal ikan tipe kayu masih tidak terlalu beresiko (Muharam, 2011). Untuk wilayah operasi kapal nelayan yang berada di pulau, akan sangat sulit untuk langsung menggantikan kapal kayu menjadi kapal baja atau kapal jenis lain selain fiberglass karena kapal baja pembangunan kapal baja membutuhkan fasilitas produksi seperti alat-alat berat yang memadai. Sedangkan untuk kapal fiberglass tidak membutuhkan fasilitas seperti alat-alat berat seperti yang telah disebutkan sebelumnya.

Nilai perbandingan L/H, L/B, dan $\mathrm{B} / \mathrm{H}$ perlu diperhatikan dalam perhitungan teknis, jenis bahan maupun ketentuan yang berlaku. Dalam desain sebuah kapal, karakteristik perbandingan dimensi - dimensi utama merupakan hal penting yang harus diperhatikan (Fyson,1985). Adapun Perbandingan tersebut meliputi:

a. Perbandingan antara panjang dan lebar (L/B) yang mempengaruhi hambatan dan kecepatan kapal. Semakin kecil nilai perbandingan $\mathrm{L} / \mathrm{B}$ akan berpengaruh pada kecepatan kapal atau kapal menjadi lambat.

b. Perbandingan antara lebar dan tinggi $(\mathrm{B} / \mathrm{H})$ merupakan faktor yang berpengaruh pada stabilitas. Jika nilai $\mathrm{B} / \mathrm{H}$ membesar akan membuat stabilitas baik tetapi di sisi lain mengakibatkan propulsive ability memburuk.

c. Perbandingan antara panjang dan tinggi (L/H) merupakan faktor yang berpengaruh terhadap kekuatan memanjang kapal. Jika nilai L/H membesar maka kekuatan longitudinal kapal akan berkurang.

Pengertian kapal ikan adalah kapal yang digunakan dalam operasi penangkapan ikan atau hewan air lainnya. Kapal ikan dapat digunakan juga untuk kegiatan pengarahan, pelatihan dan peninjauan. Berdasarkan cara atau teknik 
penangkapan ikan terdapat beberapa tipe kapal ikan: trawler, purse seiner, long liner dan Bottom gill neter.Trap Netter Perbedaan tipe alat penangkapan ikan menunjukan karakteristik yang berbeda dan hal ini berkaitan dengan perbedaan bentuk konstruksi kapal ikan.

3. Jenis - Jenis kapal ikan

a. Trawler

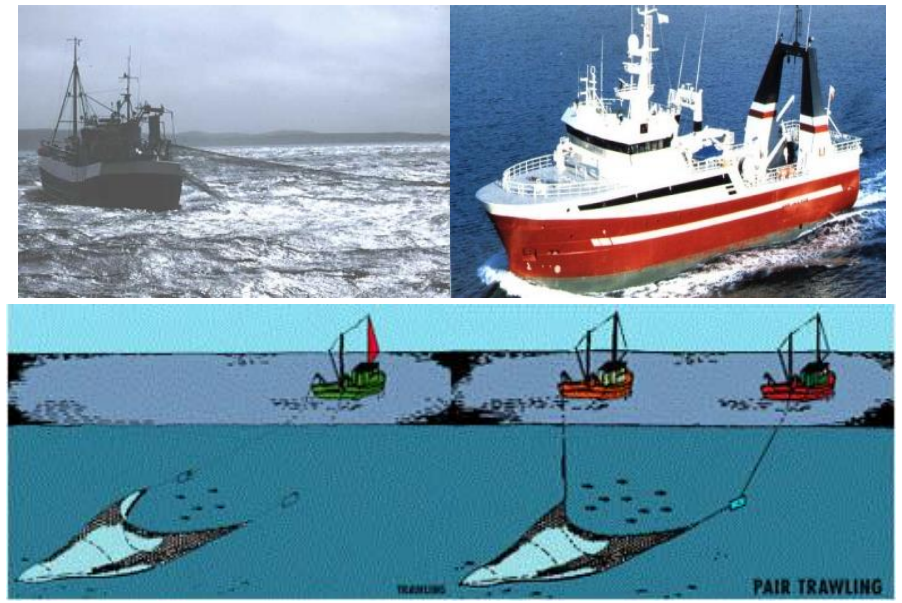

Gambar 1. 2 kapal ikan jenis trawler (jarring pukat)

(Sumber : Buku Ajar Kapal Khusus Teknik Perkapalan 2009.)

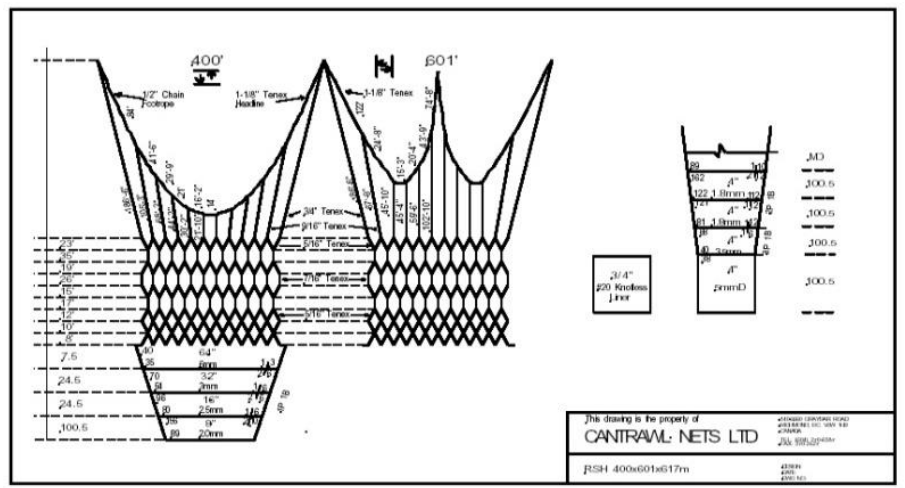

Gambar 1. 3 ukuran jarring pukat pada kapal trawler (Sumber : Buku Ajar Kapal Khusus Teknik Perkapalan 2009.) 
b. Purse Seiner (kapal ikan dengan jarring lingkar)
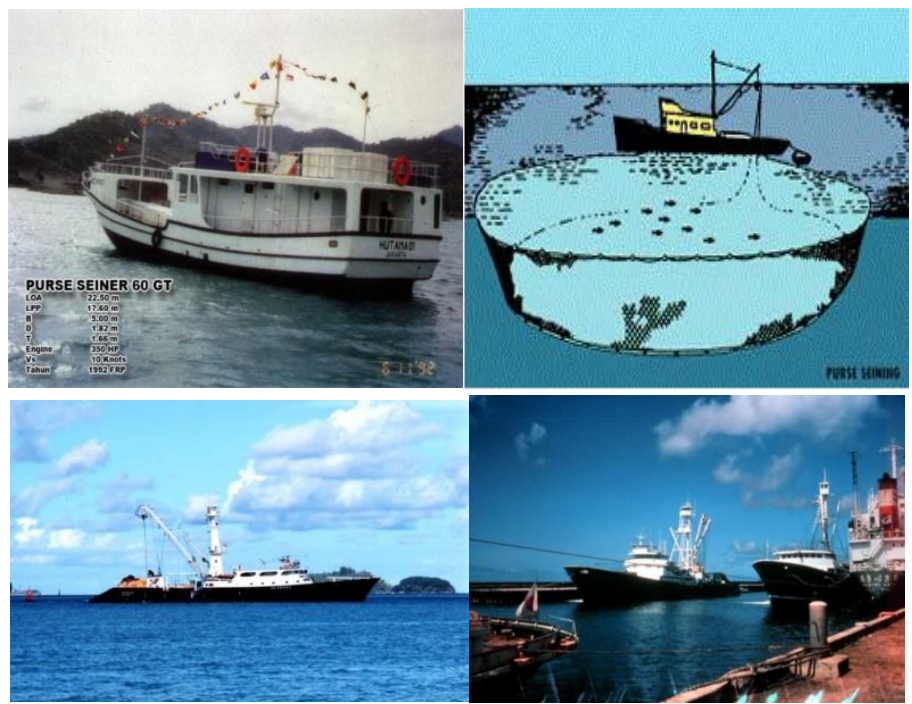

Gambar 1. 4 ikan jenis jarring lingkar

(Sumber : Buku Ajar Kapal Khusus Teknik Perkapalan 2009.)

c. Long liner (kapal rawai)

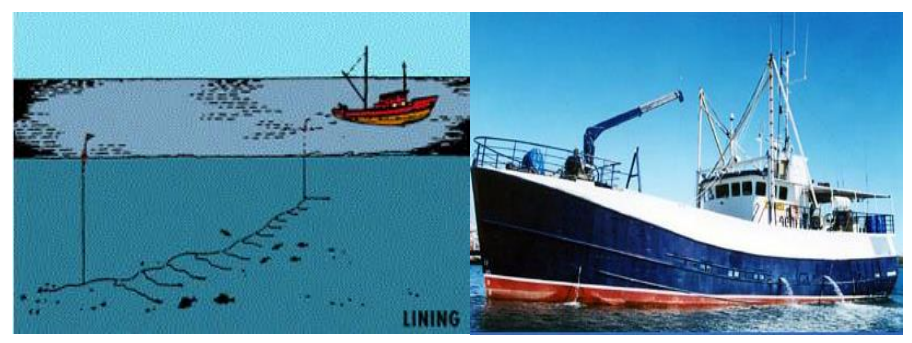

Gambar 1.5 kapal ikan jenis alat tangkap menggunakan rawai

(Sumber : Buku Ajar Kapal Khusus Teknik Perkapalan 2009.) 


\section{d. Bottom Gill Neter (Kapal Jaring Ingsang Dasar)}

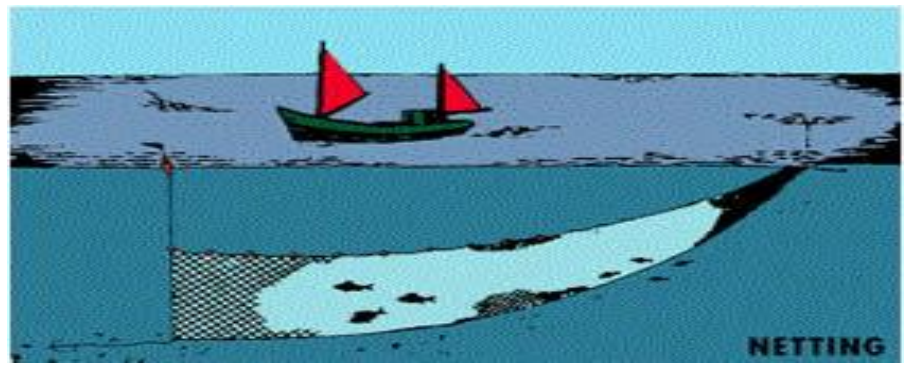

Gambar 1. 6 kapal ikan Bottom Gill Neter

(Sumber : Buku Ajar Kapal Khusus Teknik Perkapalan 2009.)

e. Fishing Traps (Kapal Bubu)
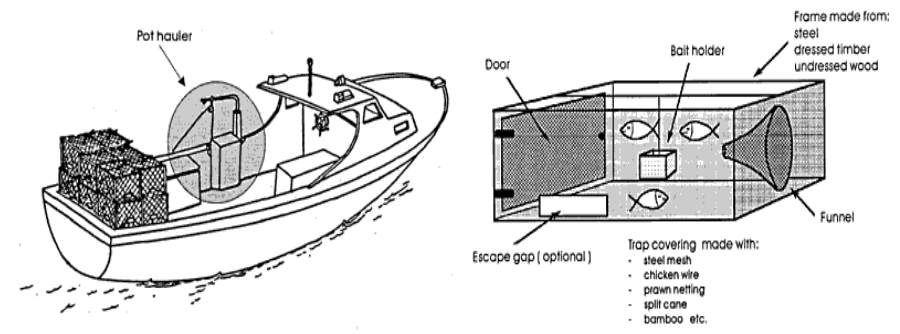

Gambar 1. 7 kapal ikan jenis alat tangkap bubu

(Sumber : Buku Ajar Kapal Khusus Teknik Perkapalan 2009.)

\section{Metode Penentuan Ukuran Utama Kapal}

1. Metode Perbandingan (comparison method)

Merupakan metode perancangan kapal yang mensyaratkan adanya satu kapal pembanding dengan tipe yang sama dan telah memenuhi criteria rancangan (stabilitas, kekuatan kapal, dan lain-lain.) dan mengusahakan hasil yang lebih baik dari kapal yang telah ada (kapal pembanding). Ukuran-ukuran pokok kapal dihasilkan dengan cara mengalikan ukuran pokok kapal pembanding dengan faktor skala (scale factor). 


\section{Metode Statistik (Statistical Method).}

Merupakan metode perancangan kapal yang mensyaratkan penggunaan data kapal- kapal dengan type yang sama yang telah dibangun dan beroperasi serta memenuhi kriteria rancangan. Dari data statistik ukuran kapal-kapal tersebut kemudian ditentukan persamaan statistik yang pada hakekatnya adalah pendekatan ratarata terhadap ukuran-ukuran kapal tersebut. Hal yang perlu diperhatikan dalam penggunaan metode statistik adalah memperbaiki secara terus menerus semua statistik dari data - data kapal baru sehingga kemungkinan kesalahan akan dapat diperkecil.

\section{Metode Iterasi / trial and error (Iteration Method).}

Rancangan kapal dengan metode iterasi pada dasarnya adalah pengembangan dari metode perbandingan dan metode statistik tetapi dilakukan secara berulang-ulang dengan koreksi pada setiap pengulangan. Ukuran pokok kapal rancangan yang dihasilkan cukup akurat karena telah dilakukan koreksi setiap kali pengulangan perhitungan, dan karena dilakukannya pengulangan tersebut maka metode ini sering juga disebut metode spiral. Ukuran-ukuran pokok kapal rancangan dihitung dengan menggunakan persamaan-persamaan empiris. Metode yang digunakan dalam penelitian untuk perancangan Kapal penangkap ikan jenis gilnet 3 GT ini menggunakan trial and error method dengan menentukan ukuran utama kapal secara berulang-ulang kali sampai dihasilkan ukuran utama kapal yang sesuai dengan kapal yang akan dirancang dalam tulisan ini ukuran kapal 3 GT, dan selanjutnya dilakukan pengecekan perbandingan ukuran utama kapal baru yang harus sesuai dengan aturan yang telah ada tentang kapal perikanan jenis purse seine dengan konstruksi kayu. 


\section{Metode Kompleks (Complexs Solutions) atau Metode Matematis (Mathematical Method).}

Pada rancangan dengan metode matematis, seluruh ukuran pokok kapal rancangan dihitung dengan menggunakan persamaan-persamaan matematis sehingga ketelitiannya cukup besar dan hampir tidak diperlukan koreksi dalam perencanaan pembuatan kapal. Akan tetapi metode ini jarang digunakan dalam merencanakan kapal, kecuali jika dikombinasikan dengan metode yang lain, misal metode perbandingan dan metode statistik.

\section{Hambatan Kapal Perikanan}

Kapal yang bergerak di media air dengan kecepatan tertentu, akan mengalami gaya hambat (tahanan) yang berlawanan dengan arah gerak kapal tersebut. Besar hambatan suatu kapal dipengaruhi oleh beberapa hal, yaitu luas permukaan basah, jenis fluida dan juga kecepatan kapal. Nilai hambatan kapal akan meningkat apabila angka Froude mengalami kenaikan (Harvald, 1983) dan (PNA, 1988). Hambatan kapal dihitung menggunakan metode numerik berbasis perhitungan software Maxsurf. Input dari perhitungan hambatan kapal menggunakan software Maxsurf adalah ukuran Utama kapal. Menurut Oortmerssen, (1971) pemilihan metode dengan perhitungan hambatan kapal dilakukan dengan kriteria sebagai berikut:

1. Savitsky pre planing: Algoritma ini digu-nakan untuk perhitungan hambatan kapal pada kapal cepat planing hull pada kondisi sebelum planing (pre planing).

2. Savitsky planing: Algoritma ini digunakan untuk perhitungan hambatan kapal pada kapal cepat planing hull yang bekerja pada kondisi planing (kecepatan planing).

3. Lahtiharju: Algoritma ini digunakan untuk perhitungan hambatan kapal pada kapal cepat planinghull pada kondisi planning (kecepatan planing). 
4. Holtrop: Algoritma ini digunakan untuk perhitungan hambatan kapal pada kapal tanker, kapal kargo, kapal ikan, tug boat, kapal kontainer dan kapal frigate.

5. Van Ootmerssen: Algoritma ini digunakan untuk perhitungan hambatan kapal pada kapal kapal kecil misalnya kapal trawler dan kapal tug boat.

6. Series 60: Algoritma ini digunakan untuk perhitungan hambatan kapal pada kapal kargo dengan satu propeller (single screw propeller).

7. Delft Series: Algoritma ini digunakan untuk perhitungan hambatan kapal pada kapal layar (sailing yacht) berdasarkan metode perhitungan regresi Gerritsma (1991) atau Gerritsma (1992).

Metode perhitungan hambatan total kapal untuk kapal kapal kecil bisa menggunakan metode Van Oormersses. Metode ini bisa digunakan untuk mengestimasi hambatan total kapal kapal kecil seperti trawlers dan tugs. Persamaan parameter parameter yang digunakan pada metode Van Oortmerssen ini diperoleh dari koleksi data - data kapal trawler dan tugs sejumlah 93 model kapal. Sebagai tambahan, metode ini juga bisa digunakan untuk memprediksi hambatan dan powering kapal tipe small craft. Pada metode ini hambatan viskous dan hambatan gelombang direpresentasikan langsung pada komponen hambatan total kapal (Total Resistance).

\section{Langkah - langkah perhitungan total resistance (RT)}

a. Menghitung volume displacement

Volume Displacement adalah volume air yang dipindahkan dan merupakan salah satu variabel penting dalam perhitungan hambatan kapal. Volume dari badan kapal yang ada di bawah permukaan air namun tidak termasuk tebal kulit, tebal lunas, tebal daun kemudi, propeller, dan segala perlengkapan kapal yang tercelup air. 